\title{
The Opportunities and Challenges of Student Paralegal within the University Legal Clinic at PTKIN
}

\author{
Deni Kamaludin Yusup ${ }^{1}$, Burhanudin Hamnach², Cate Sumner ${ }^{3}$
}

\begin{abstract}
The Opportunities and Challenges of Student Paralegal within the University Legal Clinic at PTKIN. This paper is motivated by the role of the university legal clinic under the spirit of implementing the third of university role in the field of community service. In practice, legal aid services at universities are not different from general aid agencies in general. One of the uniqueness of the university legal clinic program is the direct involvement of student paralegal in helping the clients to get legal aid services within the university and court. The student paralegal encounters various opportunities and challenges. The main opportunities, they have their passion and strong motivation to become justice fighters for justice seekers, while they have also the main challenges such as limited time, facilities, knowledge, and legal skills. However, the existence of student paralegal has proven to be very helpful for the clients not only in processing applications and registering cases in court but also in assisting clients in the form of consultation and legal assistance during non-litigation and litigation. Therefore, the university legal clinic program needs to be further strengthened and developed at PTKIN because it has proven positive implications for helping underprivileged people and justice seekers to get access to justice.
\end{abstract}

Keywords: paralegal, client, legal clinic, legal aid, access to justice

\begin{abstract}
Abstrak: Peluang dan Tantangan Paralegal Mabasiswa dalam Klinik Hukum Universitas di PTKIN. Tulisan ini dilatarbelakangi peran klinik hukum universitas sesuai dengan semangat mengimplementasikan Tridharma Perguruan Tinggi dalam bidang pengabdian kepada masyarakat. Pada praktiknya, pelayanan bantuan hukum di universitas pada prinsipnya tidak berbeda dengan lembaga-lembaga bantuan umum pada umumnya. Salah satu keunikan program klinik hukum universitas adalah keterlibatan mahasiswa secara langsung dalam membantu klien mendapatkan pelayanan bantuan hukum di lingkungan universitas dan pengadilan. Pada kenyataannya, paralegal mahasiswa menemui berbagai peluang dan tantangan. Peluang utama yang mereka miliki terletak pada semangat dan motivasi kuat untuk menjadi pejuang keadilan bagi para justice seekers, sedangkan tantangan utama yang mereka temui adalah keterbatasan waktu, sarana, pengetahuan, dan kemahiran hukum. Namun demikian keberadaan paralegal mahasiswa terbukti sangat membantu klien bukan hanya dalam mengurus permohonan dan pendaftaran perkara ke pengadilan, tetapi juga mendampingi klien berupa konsultasi dan pendampingan bantuan hukum melalui nonlitigasi dan litigasi. Oleh karena itu, program klinik hukum universitas perlu lebih diperkuat dan dikembangkan di PTKIN karena terbukti berimplikasi positif untuk membantu masyarakat kurang mampu dan pencari keadilan untuk mendapatkan akses bantuan hukum. Kata Kunci: paralegal, klien, klinik hukum, bantuan hukum, akses kepada keadilan
\end{abstract}

\footnotetext{
${ }^{1,2}$ Faculty of Sharia and Law, Universitas Islam Negeri Sunan Gunung Djati Bandung, Jl. A.H. Nasution No.105, Cipadung, Kec. Cibiru, Bandung, West Java 40614, Indonesia.

${ }^{3}$ Senior Advisor, Australia Indonesia Partnership for Justice (AIPJ), 18th floor, International Financial Centre (IFC) Building, Jl. Jend Sudirman Kav. 22-23, DKI Jakarta 12920, Indonesia.

E-mail: 1dkyusup@uinsgd.ac.id, 2burhanuddin@uinsgd.ac.id, ${ }^{3}$ catesumner@yahoo.com.au 


\section{Introduction}

Starting from anxiety over the many problems of law enforcement in Indonesia, especially the demands to fulfill the legal right and access to justice for the poor people, women, and children, managers of Universities have encouraged several initiator lecturers to establish university legal clinic at State Islamic University (SIU) or Perguruan Tinggi Keagamaan Islam Negeri (PTKIN). ${ }^{1}$ University legal clinic is designed to be a media for the lecturers and student paralegal to contribute to law enforcement and increase access to justice for the community, and at the same time become part of the implementation of the third of the university's role in the field of community service. ${ }^{2}$

Besides, to improve access to justice for the community, especially the poor people, women, vulnerable children, and the people with disabilities to legal aid services, especially those relating to access to legal identity (birth certificate, marriage, and divorce certificate), support and practice are needed from all components of society, including academicians in tertiary institutions. In this context, the university legal clinic can contribute to providing legal assistance and access to justice for the poor and marginalized people because they can reach judicial and legal institutions. ${ }^{3}$ Until now, university legal clinic is very helpful the clients in access to justice, especially for a number of Islamic family law cases in Islamic court. ${ }^{4}$

The existence of a university legal clinic in tertiary institutions is very important because it has several advantages in terms of access and

${ }^{1}$ Riyan Ramdani, et.all., Company Profile BKLHK Fakultas Syariah dan Hukum UIN Sunan Gunung Djati Bandung, (Bandung: BKLHK FSH UIN Sunan Gunung Djati Bandung, 2015), p. 1.

${ }^{2}$ The third of the university's role in the field of community service is regulated under the National Education System Law Number 20 of 2003, the National Education Standard Law Number 19 of 2005, and the Government Regulation Number 66 of 2010 on Educational Management.

${ }^{3}$ Nurkholis Hidayat, "'University Legal Clinics and Its Role in Law Enforcement Program”,' (presented at the Public Lecturer Discussion, Faculty of Sharia and Law UIN Sunan Gunung Djati Bandung, 2015).

${ }^{4}$ Nurul Adhha, 'Analysis of Causes of Divorce in the Perspective of Islamic Law: A Case Study in the Class 1 A Religious Court of Padang', $A L$-'ADALAH, 16.1 (2019), 89-114 <https:// doi.org/10.24042/adalah.v16i1.2305>. 
the ability to reach the judiciary and legal institutions. University legal clinic is also present to help part of the responsibility of the state to ensure the existing legal system can implement the principles of a clean and fair trial and recognize equality before the law without discrimination. Therefore, there is not the slightest reduction or restriction that can be done by the state to guarantee the constitutional rights of citizens to obtain equality before the law. Likewise, poverty does not diminish one's right to get defense and assistance from an advocate. Legal defense and assistance for the poor people, marginal, and other vulnerable groups will create a balance in the legal process (due process of law) so that justice will apply to everyone without exception (justice for all). ${ }^{5}$

However, due to the very limited number of advocates and the reach of advocate working areas, most of which carry out their duties in urban areas follow the dominance of the court, as well as the distribution of poor people who need legal assistance is in rural or suburban areas. the existence of student paralegals becomes an important part of helping the community to get legal assistance and access to justice. The role of paralegals is very important to reach access to justice for the poor people. ${ }^{6}$ Paralegals have also been recognized in Legal Aid Law Number 16 of 2011, which stated that legal aid providers are given the right to recruit lawyers, paralegals, lecturers, and law students. Through this regulation, student paralegal has also gained legal legitimacy so that its existence must be recognized by law enforcement officials and other relevant institutions. International legal provisions also regulate the provision of legal aid and recognition of the role of paralegals as in United Nations Principles and Guidelines on Access to Legal Aid in the Criminal Justice System. ${ }^{7}$

${ }^{5}$ Erna Ratnaningsih, 'Peran Paralegal dalam Pemberian Bantuan Hukum', Business Law, 2019 <https://business-law.binus.ac.id/2016/10/16/peran-paralegal-dalam-pemberian-bantuanhukum/> .

${ }^{6}$ Raj Kumar Verma, 'Role of Para-Legal Services in Administration of Justice: An Empirical Study of Shivpuri District', International Journal of Law, 3.4 (2017), 71-77.

${ }^{7}$ Vivek Maru, 'Between Law and Society: Paralegals and the Provision of Justice Services in Sierra Leone and Worldwide', Yale Journal of International Law, 31.2 (2006), p. $429<\mathrm{https} / /$ digitalcommons.law.yale.edu/yjil/vol31/iss2/5>. 
Referring to the reason, the number of expert lecturers who teach at the Faculty of Sharia and Law at PTKIN have taken the initiative to conduct a preliminary study on how to design a university legal clinic program, prepare students training to enable them to practice legal aid, establish cooperation with court institutions, government agencies, and non-government organization. In the last few years, it was noted that the role of student paralegals was very impressive in helping every client dealing with legal issue, in the form of direct assistance in administering the making of a lawsuit, request letter, power of attorney, registering a claim or request to court, assisting during proceedings at court, and other legal assistance.

\section{Who Is A Student Paralegal?}

A paralegal is someone who has legal skills but he is not a professional lawyer and works under the guidance of a lawyer or who is judged to have the legal ability to use his skills. ${ }^{8}$ The term "paralegal", first listed in the legislation is in the Law of Legal Aid Number 16 of 2011. In Article 9 of the provision, it is stated that "legal aid providers are entitled to recruit lawyers, paralegals, lecturers, and law students". ${ }^{9}$ Meanwhile, in Article 10, it is stated that "legal aid providers are obliged to organize legal aid education and training for advocates, paralegals, lecturers, and law students. ${ }^{10}$

If we refer to Article 1 Point 2 and 3 in the Law of Legal Aid Number 16 of 2011, the legal aid is mean the exercising power of attorney, assisting, representing, defending, and/or carrying out other legal actions for the legal benefit of the legal aid recipient. ${ }^{11}$ Although it only gained formal legitimacy by the term "paralegal" after the enactment of the Law of Legal Aid, in the number of previous laws and regulations, it has provided a lot of legitimacy for the paralegal position, even

${ }^{8}$ Editor, 'Paralegal - LBH APIK' <https://lbhapik.or.id/paralegal/> [accessed 7 November 2019].

${ }^{9}$ Article 9-10 the Law of Legal Aid Number 16 of 2011.

${ }^{10}$ Siti Aminah dan Muhamad Daerobi, Paralegal Adalah Pemberi Bantuan Hukum, Jakarta: The Indonesian Legal Resource Center, 2019, p. 1.

${ }^{11}$ Article 1 Point 2 and 3 in the Law of Legal Aid Number 16 of 2011. 
though with different mentions. ${ }^{12}$ For example, Law Number 23 of 2004 concerning the Elimination of Domestic Violence uses the term "volunteer companion"13 to refer to the term "paralegal", whereas in the Law of Children Court Number 3 of 1997 uses the term "social worker". ${ }^{14}$

The term paralegal was known in Indonesia around 1975. Previously, during the Dutch occupation, paralegal was better known as Pokrol or Gemachtegde. ${ }^{15}$ Based on the historical side, paralegals are initially emerged as a reaction to the powerlessness of the law and the legal profession in understanding and capturing and fulfilling the social assumptions needed to realize the rights of the poor people which are recognized by law. The exercise of these rights can often only be carried out if the social assumptions are fulfilled by several reasons: firstly, the community understands its rights, and secondly, the community must fight for the realization of these rights.

At a glance, it can be emphasized here that student paralegals are every student who has been trained and has knowledge and skills in the field of law, and can help resolve legal problems faced by other people or their communities. In carrying out their role, usually, a paralegal student gets supervision by lecturers at universities and advocates who work in professional legal aid organizations. The presence of student paralegals may become a bridge connecting lecturers, advocates, with communities of justice seekers who are in the areas that are difficult to reach by the lecturers and advocates. ${ }^{16}$

${ }^{12}$ YLBHI, Verboden Voor Honden En Inlanders dan Lahirnya LBH: Catatan 40 Tahun Pasang Surut Keadian, Jakarta: Yayasan Lembaga Bantuan Hukum Indonesia, p. 56.

${ }^{13}$ Article 15 the Law of the Elimination of Domestic Violence Number 23 of 2004.

${ }_{14}$ The term of paralegal is regulated under Article 1 the Law of Children Court Number 3 of 1997, Article 1 Point (12) the Law of Children Protection Number 23 of 2002, Article 1 point (4) the Law of Social Employer Number 14 of 2019, Article 9-10 the Law of Legal Aid Number 16 of 2011, the Constitutional Court Decision Number: 88/PUU-X/2012 on $19^{\text {th }}$ December 2013, the Government Regulation Number 42 of 2013 on Requirement and Procedure for Legal Aid and Financial Distribution of Legal Aid, and the Ministry of Law and Human Rights Regulation Number 1 of 2018 on Paralegal in Legal Aid Services.

${ }^{15}$ Chandra Muliawan, 'LBH BANDAR LAMPUNG | Bantuan Hukum Di Lampung | Membumikan Bantuan Hukum Struktural Melalui Penguatan Paralegal', LBH Bandar Lampung | Bantuan Hukum Gratis Di Lampung <http://bantuanhukumlampung.or.id/opini_lbhbandarlampung. php?judul_opini=Membumikan+Bantuan + Hukum + Struktural + Melalui+Penguatan + Paralegal $>$ [accessed 7 November 2019].

16 'Agar Mahasiswa FH Boleh Beracara Di Pengadilan - Hukumonline.Com’ <https://www. 
The most fundamental thing to optimize the role of student paralegal in legal aid programs is not only ideally limited by certain conditions where students must have passed the event law course. The Law of Legal Aid itself does not explicitly mention whether the passing scores are A, $\mathrm{B}$, or $\mathrm{C}$; also it does not mention whether it deals with all procedural law or sufficient for a criminal procedure or civil procedure. The most important requirement is the student must have a strong interest and motivation to participate in paralegal training. Article 13 point (4) the Government Regulation Number 42 of 2013 only states that the law student must have passed procedural law and paralegal training courses.

Thus the existence of student paralegals at university legal clinics today has existed and developed to fulfill these social assumptions. Throughout its development, the student paralegals at the university legal clinic have also been automatically recognized for their legitimacy in the laws and regulations in Indonesia, as well as their roles and functions that continue to grow following the needs of the justice seekers community in various fields of life.

\section{How University Legal Clinic Are Formed?}

The formed of a university legal clinic is part of the clinical legal education programs at the universities. ${ }^{17}$ It is also become part of community service and must be supported by the government to fulfil the rights to law and access to justice for all society. ${ }^{18}$ The legislation of the legal aid law is one of the efforts for the government and the state in ensuring the constitutional right for everyone to obtain equitable recognition, to guarantee, to protect, and to fulfil legal certainty and equal treatment before the law as a means of human rights protection. ${ }^{19}$

hukumonline.com/berita/baca/lt51e905308efd3/agar-mahasiswa-fh-boleh-beracara-di-pengadilan/>

${ }^{17}$ Dave Holness, 'Improving Access to Justice Through Compulsory Student Work at University Law Clinics', Potchefstroom Electronic Law Journal, 16.4 (2013), 327-49 (pp. 6-7) $<$ https://doi.org/10.17159/1727-3781/2013/v16i4a2417>.

${ }^{18}$ Joseph E. Rupp, 'Veterans Legal Clinic - An Integrated Approach to Pro Bono Legal Consultation', Utah BAR Journal, 32.6, p. $63<<$ http://barjournal.utahbar.org/ uploads/9/1/9/4/91940160/nov_dec_2019_final.pdf>.>.

${ }^{19}$ Article 1 the Law of Human Rights Number 39 of 1999. 
In Indonesian legal system, clinical legal education program is proposed to implement the mandate contained in the constitution to fulfill the right to law and justice and it is also relevant to the objective of the Law of Legal Aid Number 16 of 2011, where the government is obliged to (1) prepare and stipulate the policies for the provision of legal aid; (2) prepare and establish a legal aid standards based on the principles of the provision of legal aid; (3) arrange the draft of the legal aid budget plan; (4) manage the legal aid budget effectively, efficiently, transparently and accountably; and (5) prepare and submit reports on the provision of legal aid to the house of representatives at the end of each fiscal year. ${ }^{20}$

Referring to the experience of the Faculty of Sharia and Law of UIN Sunan Gunung Djati Bandung, the initial phase of the establishment of a university legal clinic was established in 2012 based on the following policies: ${ }^{21}$

1. Legality Policy, namely structuring aspects of organizational legality governed by Decree of the Faculty Dean or Rector's Regulation. This aims to ensure that the position of the university's legal clinic gets a strong legal umbrella as a non-structural institution under the faculty or university;

2. Academic Policy, namely the legal clinic as a subject that has a minimum practical weight of 2 Credits and is integrated into the Curriculum System of the Faculty of Sharia and Law;

3. Learning Policy, which makes the legal clinic as a learning material that must be followed or selected electively by students to improve legal skills;

4. Level policy, which is to make a legal clinic that can only be taken by students in Semester 6 along with the implementation of a professional practicum or expertise program;

${ }^{20}$ Article 9-10 the Law of Legal Aid Number 16 of 2011.

${ }^{21}$ Deni Kamaludin Yusup, Ah. Fathonih, and Burhanuddin, University Legal Clinics: A Comparative Study in BKLHK FSH UIN Sunan Gunung Djati Bandung and FLAP Faculty of Law Monash University Melbourne Australia (Bandung: Puslitpen LP2M UIN Sunan Gunung Djati Bandung, 2016), p. 139. 
5. Restrictions Policy, which is to make the law clinic an additional lecture program that can be followed by students in Semesters 1-5 who join the community of law activists;

6. Conditional Policy, namely making the legal clinic an apprenticeship program in legal aid organizations especially for law students who have passed the Law procedure and Professional/Expertise Practicum Course;

7. Funding Policy, namely making the legal clinic financed from government funding sources, universities or faculties, partnerships, sponsorships, and some of which are not prohibited by law.

In terms of its organizational structure, the university legal clinic Faculty of Sharia and Law UIN Sunan Gunung Djati Bandung have many similarities with the university legal clinic in general, which consist of general responsible, implementing responsible, consultant, and daily executors. The person in charge is directly in the hands of the Dean of the Faculty of Sharia and Law, while the person in charge is the Chairperson and the Secretary of the Department. Each has different duties and authorities according to his position. ${ }^{22}$

Then the Consultant Team consists of expert lecturers who must foster and guide students in providing consulting services and legal assistance to clients, including implementing education and training programs. The day-to-day organizers consist of some lecturers and student paralegals who work daily providing consulting services and legal assistance to clients on campus and around the court. In simply, the organizational structure of a university's legal clinic can be described as follows: ${ }^{23}$

${ }^{22}$ BKLHK, BKLHK Annual Report 2013-2015 (Bandung: Department of Islamic Family Law Faculty of Sharia and Law UIN Sunan Gunung Djati Bandun, 2015), p. 9.

${ }^{23}$ BKLHK, BKLHK Annual Report 2013-2015, p. 10. 
Figure 1: Organizational Structure of the University Legal Clinic

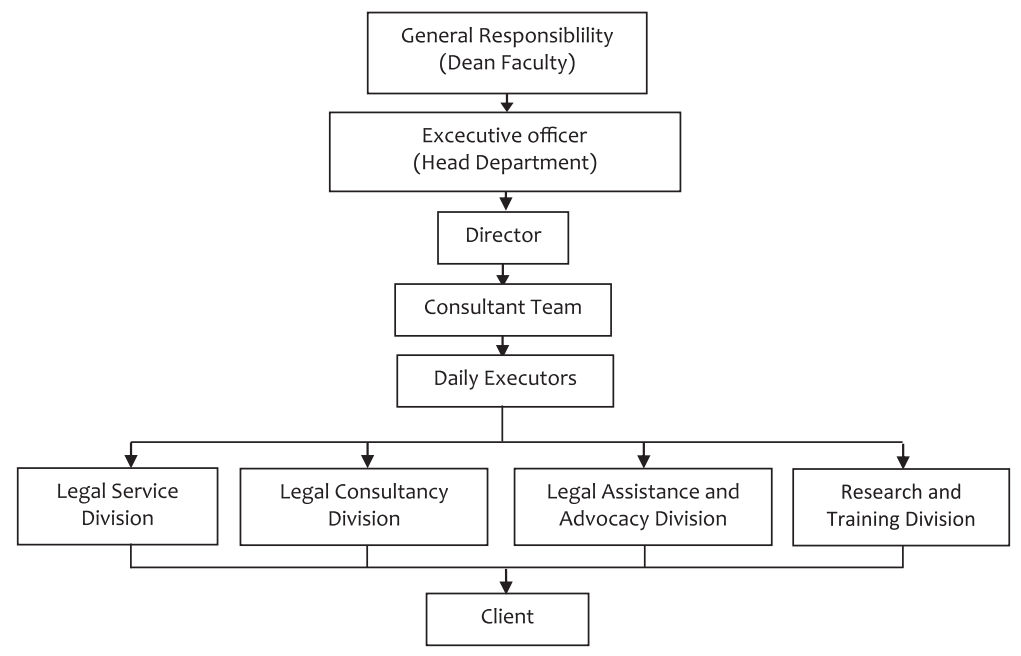

Based on the structure above, the existence of a university legal clinic is part of the implementation of the role of the university in terms of community service. Besides, it can be seen as a practical place for law students to prepare their works in the field of legal practice. Thus, the implementation of clinical law education program is very important to be taught by the law students in higher education institution with the following objectives: ${ }^{24}$

1. The clinical law education program is aimed to provide the structure of educational opportunities for the law students to augment their experiences in the actual practice of legal service or through the practical simulation of legal assistance to the clients, as well as to acquire the knowledge, expertise, and values of the experience;

2. University legal clinic is intended to supplement support for legal assistance to marginalized people or community;

3. University legal clinic is intended to install the spirit of public service and social justice, and to establish the basis for the development of legal profession responsibilities;

${ }^{24}$ Ramdani Wahyu Sururie, 'The Importance of University Legal Clinics in Public Legal Aid Service' (presented at the Public Lecturer Discussion, Bandung: PKHSK Faculty of Sharia and Law UIN Sunan Gunung Djati, 2015). 
4. The supervisor lecturers at university legal clinic may contribute to the development of a scholarship on the skills and theories of practical law that link to the academic world with the parish organization more closely;

5. The using of interactive and reflective teaching methods is motivated to perform the student role in several activities like mentioned above, which are not obtained in a formal college. Furthermore, this reflective method of learning has also proven to be the most effective way of enduring the student's learning;

6. The existence of a university legal clinic is aimed at strengthening the role of the student paralegal towards the realization of civil society through maintaining and caring for the professional responsibilities of lawyers to obtain the emphasis of legal aid service needs and to protect the right to justice for all marginalized peoples.

To strengthen the university legal clinic, AIPJ and PTKIN collaborated to hold a national workshop on strengthening the role of university legal services in Indonesia which was held 5-7 May 2014 in Bandung by presenting Professor Malcolm Bennett and his assistant, Jennifer Lindstrom, from Family Assistance Program (FLAP), Faculty of Law, Monash University, Melbourne, Australia. ${ }^{25}$

Figure 2: AIPJ-PTKIN Collaboration for University Legal Clinic Development

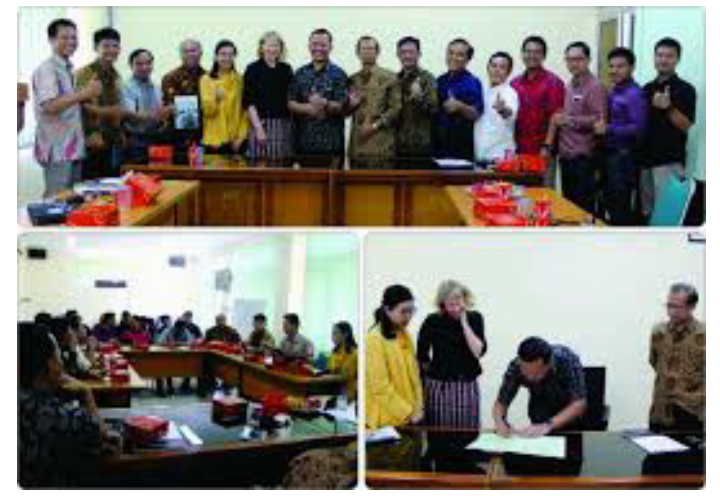

${ }^{25}$ Cate Sumner, 'Memperkuat Layanan Hukum Di Perguruan Tinggi', 2019 <”, http:// archive.aipj.or.id/en/legal_identity_new/detail/memperkuat-layanan-hukum-di-perguruan-tinggi> 
The workshop was organized by AIPJ and attended by around 25 participants from 5 universities in Indonesia, relevant government agencies, Civil Society Organizations (CSOs) and Disability Organizations (OD). The workshop focused on improving the learning system in the faculty of sharia and faculty of the law so that it could support students in providing professional legal consultation and assistance.

The final aim of the workshop is that the legal clinic at the faculty of sharia and faculty of law can assist paralegals from CSOs and ODs in providing legal services to the poor, poor women, children and disability groups, relating to family law and ownership legal identity. The legal consulting service at a university legal clinic is known as a professional and quality service, not inferior to the services provided by legal aid organizations that are of a profit nature.

\section{How To Improve Student Paralegal Skills?}

Such is the importance of the existence of student paralegals to help the justice seeker community, university legal clinic is a media for the students at faculty of law whose essence aims to provide clinical-based legal education program and to put forward the knowledge, practical skills, and values, which is to develop the student's knowledge, to have practical skills in law, and encouraging them to have the values of social justice and professional ethics. ${ }^{26}$ The clinical legal education program is based on a legal clinic at a higher educational institution that can be done at least in three stages: ${ }^{27}$

1. The planning component is the preparation time for the students at the university legal clinic program. At this stage, the law students are firstly equipped with knowledge that is directly related to practical activities to be implemented in the practice of legal aid service by students, such as:

${ }^{26}$ Helen Dancer, 'Power and Rights in the Community: Paralegals as Leaders in Women's Legal Empowerment in Tanzania', Feminist Legal Studies, 26.1 (2018), 47-64 (pp. 47-50) <https://doi.org/10.1007/s10691-018-9371-6>.

${ }^{27}$ Ah Fathonih, 'University Legal Clinics In The Fulfillment Of Women And Children Rights', International Journal of Scientific \& Technology Research, 8.4 (2019), 133-40 (p. 135). 

a. Mastery of legal theory;
b. Ability to analyze cases;
c. Ability to apply the legal theory.

2. The experiential component is the stage for the students to perform his or her legal skills in the practice of legal aid service, which includes:
a. The ability to interview the clients (client interviewing exercises);
b. The ability to negotiate exercises and transaction exercises;
c. The ability to formulate arguments and defenses (legal writing and argument drafting programs).

3. Reflection is the stage for the students to carry out the evaluation and assessment of the learning processes that have been passed, which includes:
a. The ability to self-evaluate;
b. Ability to hold peer review;
c. Ability to accept criticism from the supervisor.

4. The basic knowledge that must be possessed by the students in practicing the wheels of legal education in the university legal clinic environment are:

a. The principle of social justice and its application in the professional field;

b. The ethics of the legal profession;

c. Interview skills.

In practice, it can be said that a university legal clinic program is run by the student paralegal under lecturer supervision, which is governed by the same rules against the Legal Aid Institute outside the university. ${ }^{28}$ Meanwhile, the existence of a university legal clinic at the scope of the university role became its operational base. But in some countries like Africa and Latin America, law offices in the community providing legal

${ }^{28}$ Magdalena Sepúlveda Carmona and Kate Donald, 'Beyond Legal Empowerment: Improving Access to Justice from the Human Rights Perspective', The International Journal of Human Rights, 19.3 (2015), 242-59 (pp. 242-45) <https://doi.org/10.1080/13642987.2015.1 $029340>$. 
services are also called a legal clinic. ${ }^{29}$ All faculty of law may run a legal aid service in communities through university legal clinics as a special place for local alumni, students, lecturers, and volunteers to provide the practice of legal aid, legal assistance, and legal consultancy. ${ }^{30}$

There are many different types of university legal clinic program available and run by the universities, the types vary greatly and depend on many factors, both internally and externally. Based on the location of the practice, two types of university legal clinics are at the scope of a university (in-house clinic) and outside the university (out-house clinic). Each has its characteristics and models. For instance, the university legal clinic program from out-house clinic consist ${ }^{31}$

1. In externship scope, the students are working at law firm office, judicial office or the government office under the supervision of a practicing lawyer or a government official;

2. Community Clinic, where the students work directly in the community;

3. Mobile Clinic, where the students visit the community to give legal opinions and or to notify the community of their rights or to advice on certain types of legal issues and how to solve them.

Until now, the university legal clinic program also may be practiced from an in-house clinic which consists of life client or real client clinic, where students provide legal services directly to clients, and simulation clinic, in which students simulate real-life based on role-playing to train students' faculty skills. Usually, real cases are used in this simulation clinic. The most popular university legal clinic model has often termed the street law clinic, which provides legal and rights education such as Junior High School and Senior High School students as well as those who tend to be marginalized. In addition to discussing issues on citizenship

\footnotetext{
${ }^{29}$ Ambreena Manji, “"Her Name Is Kamundage”: Rethinking Women and Property Among the Haya of Tanzania', Africa, 70.3 (2000), 482-500 <https://doi.org/10.3366/afr.2000.70.3.482>.

${ }^{30}$ Dio Ashar Wicaksana, 'Pengembangan Klinik Hukum FHUI dan Pembentukan Klinik Anti Korupsi', MaPPI FHUI, 2015 <http://mappifhui.org/2015/05/01/pengembangan-klinikhukum-fhui-dan-pembentukan-klinik-anti-korupsi/> [accessed 9 November 2019].

${ }^{31}$ Nurkholis Hidayat.
} 
rights, students can also discuss basic legal understanding such as the sale and purchase of land, the writing of wills and others. But as part from all its forms, the university legal clinic also features as follows: (1) a component to teach skills and the values about social justice and addressed to planning component), (2) a component to apply those skills within a practical setting (intended for practice settings); and (3) reflection and evaluation (component of reflection and evaluation). In other words, in the university legal clinic program, the students follow the university legal clinic course by obtaining credit.

In practice, the students accompany their clients in real-time in which a time for them to attend lectures within the legal aid service that can enrich them through their fieldwork. The structure of fieldwork is almost the same, which is parallel with the seminars, and also used in the externship program. The lecturers who are working as a supervisor at the university legal clinic guide their students with a limited number of cases as part of the important lessons for service to the community. The lecturers have a responsibility to supervise student activities, whether they are working in litigation activities or other types of legal services. So it is only done through the planning and balance of all components that make the goals of university legal clinic education will be achieved.

\section{How does Student Paralegal work in University Legal Clinic?}

The existence of the university legal clinic is important to assist the community in obtaining the right to law and justice. In carrying out its duties and functions, We can refers to the work program of university legal clinic at Faculty of Sharia and Law UIN Sunan Gunung Djati Bandung, which has manuals and operational guidelines for implementing operational programs, specifically in providing legal services, legal consultation, advocacy, and legal assistance, as well as education and training, including legal counseling to the community. ${ }^{32}$

${ }^{32}$ Yogie Arif Maulana, BKLHK Annual Report 2015-2018, Bandung: Department of Islamic Family Law Faculty of Sharia and Law UIN Sunan Gunung Djati, 2018, p. 11. 
Table 1

University Legal Clinic Work Program Faculty of Sharia and Law UIN Sunan Gunung Djati Bandung ${ }^{33}$

\begin{tabular}{ccccc}
\hline No & Program & Time & Activity & Aim and Target \\
\hline 1 & $\begin{array}{c}\text { Legal Aid } \\
\text { Services }\end{array}$ & $\begin{array}{c}\text { Monday-Friday } \\
(08.00-16.00)\end{array}$ & $\begin{array}{c}\text { All Forms of Legal } \\
\text { Services }\end{array}$ & Client \\
\hline 2 & $\begin{array}{c}\text { Legal } \\
\text { Consultation } \\
\text { Services }\end{array}$ & $\begin{array}{c}\text { Monday-Friday } \\
(08.00-16.00)\end{array}$ & $\begin{array}{c}\text { Legal Procedure in the } \\
\text { Court and Call Centre } \\
\text { Services }\end{array}$ & Client \\
\hline Advocacy and & $\begin{array}{c}\text { Monday-Friday } \\
(08.00-16.00)\end{array}$ & $\begin{array}{c}\text { Providing advocacy, } \\
\text { mediation, and legal } \\
\text { assistance }\end{array}$ & Client \\
\hline & $\begin{array}{c}\text { Legal Assistance } \\
\text { Legal Education } \\
\text { and Training }\end{array}$ & Conditional & $\begin{array}{c}\text { Providing Legal } \\
\text { Education and } \\
\text { Training }\end{array}$ & $\begin{array}{c}\text { Student and } \\
\text { Client }\end{array}$ \\
\hline
\end{tabular}

During its development period in 2015-2018, many cases and clients handled by student paralegal at university legal clinic Faculty of Sharia and Law UIN Sunan Gunung Djati Bandung. They also continue to experience a significant increase along with the Legal Aid Program or Posbakum. Posbakum is practically established in a mentoring program funded by the government whose budget is deposited in every judicial institution, including in religious court to help the clients who are unable to access free legal aid (prodeo). This is managed by student paralegal in the form of an internship program through university legal clinic and amazingly it has helped quite a lot of handling and settlement of cases proposed by the public (clients). ${ }^{34}$

${ }^{33}$ Deni Kamaludin Yusup, Ah. Fathonih, and Burhanuddin, Penguatan Klinik Bantuan Hukum Universitas di PTKIN, Bandung: Puslitpen LP2M UIN Sunan Gunung Djati Bandung, 2019, pp. 208-9.

${ }^{34}$ Yogie Arif Maulana, BKLHK Annual Report 2015-2018, p. 12. 
Table 2

Case Accompaniment Performance Record at University Legal Clinic Faculty of Sharia and Law UIN Sunan Gunung Djati Bandung The Year 2015-2018

\begin{tabular}{clcl}
\hline No & \multicolumn{1}{c}{ Program } & Volume & \multicolumn{1}{c}{ Activity } \\
\hline $\begin{array}{l}\text { Services in making power of attorney, } \\
\text { letter of claim, request, response and } \\
\text { or exception }\end{array}$ & $\begin{array}{c}4762 \\
\text { Documents }\end{array}$ & $\begin{array}{l}\text { Performed Every Day, an Average of 1 } \\
\text { Month 100 Documents, in the form of } \\
\text { a Lawsuit and Application }\end{array}$ \\
\hline 2 & Legal Aid Services Through Advocate & 78 Cases & An average of 2 cases in 1 Month \\
\hline 3 & $\begin{array}{l}\text { Legal Information Services in the Form } \\
\text { of Enriching Legal Awareness Horizons }\end{array}$ & 12 Times & An Average of 1 Time in 1 Month \\
\hline 4 & $\begin{array}{l}\text { The Service Provides Legal Identity } \\
\text { Counseling }\end{array}$ & 24 Times & An Average of 1 Time in 1 Month \\
\hline 5 & $\begin{array}{l}\text { Legal Information Services by } \\
\text { Telephone (Call Centre) }\end{array}$ & 87 Times & An Average of 3 Persons in 1 Month \\
\hline 6 & Other Legal Aid Services & 36 Times & An Average of 2 Persons in 1 Month \\
\hline
\end{tabular}

Referring to Hukumonline's records, law students usually gain a lot of knowledge in various training at legal aid institutions. An internship program at a lawyer's office is another option. The Community Legal Aid Institute, for example, offers internships to law students every year. In July 2019, 10 law students passed the program. Besides the internship program, there is still a regular internship program at a legal aid organization. Such conditions will facilitate and provide more free space for them to contribute more to legal aid programs. ${ }^{35}$

In recent years, the legal aid program implemented by BPHN in expanding access to justice for the poor people can accommodate student paralegal in legal aid services through non-litigation. Efforts to develop legal counseling, paralegals, and integrated legal assistance so that the estuary of dispute resolution in court can be reduced and even reduce the number of prisoners who are over capacity.

\section{Student Paralegal Role: Opportunities and Challenges}

There are several challenges faced by student paralegal at university legal clinic in implementing their duties, namely: (1) the low interest of lecturers and students is still low to become mentors and volunteers at university

35 'Agar Mahasiswa FH Boleh Beracara di Pengadilan - Hukumonline.Com’. 
legal clinic; and (2) the lack of support from university/faculty leaders is still limited, both in terms of regulation and funding and supervision. However, they continue to address these challenges with the following solutions: (1) encouraging lecturers and students to be actively involved in the university legal clinic; (2) strengthen regulations for the existence of university legal clinic; (3) establishing partnership programs with all relevant institutions; and (4) asking for support from the government and university/faculty leaders to optimize the role and existence of university legal clinic. ${ }^{36}$

The development and challenges of the clinical legal education program today seem to be more complex. However, the orientation of clinical legal education developed at the university which can be seen in the terms of its function within three important tasks, such as education, research, training, and social community service programs. ${ }^{37}$ However, these functions must be implemented to be under the role of higher education. Concerning the current legal education task, it seems necessary to see how the curriculum used that will process the input-in this case, is the students as the input - into an output - i.e. graduates of law faculty who are proficient in the field of legal expertise as expected. ${ }^{38}$

The importance of the existence of the university legal clinic at PTKIN is established so that every Bachelor of Law has proper competence. For example, the desired competence for any Bachelor of Law wishing to be produced by Faculty of Sharia and Law at PTKIN at least becomes a researcher, teacher, practitioner, or consultant in the field of law. Each graduate of the Faculty of Sharia and Law at PTKIN is required to have the ability standard to understand, design, implement and operationalize the legal concepts and theories, including skills in using information technology system, compile, analyze, and solve the problems in the field of law comprehensively.

${ }^{36}$ Hartono Marjono, Peluang Dan Tantangan Pengacara Syariah di Peradilan Agama, Jurnal Mimbar Hukum Number 17 Year (Jakarta: Al-Hikmah and Ditbinpera, 1994).

${ }^{37}$ Andrea Cornwall and Celestine Nyamu-Musembi, 'Putting the "Rights-based Approach" to Development into Perspective', Third World Quarterly, 25.8 (2004), 1415-37 <https://doi.or g/10.1080/0143659042000308447>.

${ }^{38}$ ILRC, Pendidikan Hukum Klinik: Sebuah Tinjauan Umum, Jakarta: Indonesian Legal Resource Center, 2009. 
Similarly, the legal skill component is more focused on the ability and mastery of law students in law enforcement practices inside and outside the court, such as lawyering techniques, advocacy skills, and others. In this context, the legal value component becomes the most important moral foundation and must be owned by every law student related to their alignment in upholding the values of law and social justice in society. This policy must be regulated under the academic consideration for all law students who will be experts in the field of legal aid services. ${ }^{39}$

Moreover, it is also related to the quality standard of law graduates and the role of the university in social development programs in which a university legal clinic is a place for the students for providing consultation services and legal assistance to the clients. In this context, this expertise reflects the real efforts taken by individuals and legal aid agencies to serve the needs of legal services to clients. ${ }^{40}$ This is very relevant to the function of providing legal advisory and legal assistance services due by the university legal clinic program as part of academic activities offered by a person or legal aid institution to the community or someone who is served and intangible or everyone who cannot be owned by any other person.

\section{Strengthening Student Paralegal Role in University Legal Clinic}

To strengthen paralegal student role in university legal clinic, it is also simply seen as the embryo of clinical legal practice that comes from the lecturers and law students at universities that aim to provide legal consultation, legal assistance, and legal service to the community before they go directly to the more professional sphere in legal aid institution or become the reality of law enforcement apparatus. However, this does not imply that the lecturers and student paralegals at the university legal clinic are considered not as proficient as lawyers or professional advocates since many cases assisted and accompanied by the lecturers and law students are fully handled professionally.

${ }^{39}$ Editor, 'Utrecht University School of Law: Clinical Programme on Conflict, Human Rights, and International Justice', International Journal on Human Rights at Utrecht University, 2010.

${ }^{40}$ Malcolm Bennett, "'Monash Law Clinics”'<Malcolm Bennett,>. 
Cate Sumner, senior advisor for Legal Identity and Access to Justice at AIPJ, acting as the main facilitator in the working meeting, emphasized that the working meeting organized by AIPJ was aimed at increasing the role and capacity of universities in strengthening legal service programs for justice seekers through the university legal Aid Clinic partnership. According to Cate Sumner, AIPJ strongly supports the collaboration of universities and other institutions in the legal aid clinic program for justice seekers in Indonesia. ${ }^{41}$

In practice, the consultation and legal assistance services practiced at university legal clinics include several civil and criminal objects. The nature of university legal clinic is as a starting point container for the justice seeker community who need legal protection and justice guarantee over any case or legal event it faces in the form of legal consultation, discussion, audience, mediation, service of making a suit or petition to the judiciary and other legal services performed outside the court system. ${ }^{42}$

Currently, the development of university legal clinic is not simply giving any benefit for the law students to improve their skills and experiences, but it also shows a significant role in helping the clients who need to legal aid service and access to justice in the various areas of law such as the private or public law, family law, commercial law, contract law, and arbitration law, also immigration law, environmental law, intellectual property rights, defense law in criminal justice, criminal prosecution law, human rights law, international criminal law, etc. ${ }^{43}$

In the context of providing legal aid to the poor, the presence of law students is very important especially in areas where there are inadequate numbers of lawyers, law lecturers, and paralegals. In the process of establishing the Law of Legal Aid and its technical regulations,

${ }^{41}$ Cate Sumner, 'University and Community Paralegal Clinics: A Decade of Collaboration between Indonesia and Australia', Themis Says, 2018 <https://feministlegalstudies.wordpress. com/2018/12/17/university-and-community-paralegal-clinics-a-decade-of-collaboration-betweenindonesia-and-australia/>.

${ }^{42}$ Cate Sumner.

${ }^{43}$ Editor, 'Peran Dan Fungsi Pekerja Sosial Sebagai Seorang Pendamping Terhadap Anak Yang Berkonflik Dengan Hukum’ <http://pn-karanganyar.go.id/main/index.php/berita/artikel/995peran-dan-fungsi-pekerja-sosial-sebagai-seorang-pendamping-terhadap-anak-yang-berkonflikdengan-hukum> 
we hope that it is more than just assistance by advocates. Furthermore, in areas with minimal advocacy, student paralegal should be allowed to help the poor people in the litigation process. The conditions, however, still need to get permission from the local court chairman. It is expected that the students will be able to hold lawsuits in areas where there is no or a lack of advocates, although, certainly, it will remain under the head of the court and authorization system. ${ }^{44}$

Moreover, there is no need for a case limitation that can be handled. There is no need to worry about student paralegals taking the quota advocate. In general, student paralegal is more focused on handling various cases involving the community. The restriction on the court stage for student paralegal is also not necessary. Article 15 The Government Regulation Number 42 of 2013 has also accommodated the provision of assistance or exercising power of attorney. According to some perspective, in disaster areas, students, lecturers, and paralegals can also provide legal assistance to victims within the university legal clinic. Government Regulation Number 39 of 2012 on the Implementation of Social Welfare includes legal aid as part of social protection. This regulation provides a space for residents who experience social vulnerability to get legal aid services.

Shortly, we can emphasize that student paralegal may accompany or exercise power of attorney at the level of investigation, prosecution, face trial, or exercise power of attorney for legal aid recipients in the administrative court. In areas with minimal advocacy, student paralegal can also carry out the task of providing non-litigation in legal assistance, to serve legal counseling, legal consultation, case investigation, legal research, mediation, negotiation, community empowerment, and drafting of legal documents.

44 'Dirjen Badilag dan 4 Pimpinan Peradilan Agama Diundang AIPJ Kunjungi Australia | (8/7) - Direktorat Jenderal Badan Peradilan Agama’ <https://badilag.mahkamahagung.go.id/ seputar-ditjen-badilag/seputar-ditjen-badilag/dirjen-badilag-dan-4-pimpinan-peradilan-agamadiundang-aipj-kunjungi-australia-87> 


\section{Conclusion}

Referring to the description above, we can say that the existence of student paralegal at university legal clinics can become one of the ideal "axis" for all lecturers to foster student talent and motivation and to form a good vision for future career opportunities. Therefore, the role of student paralegal at university legal clinics cannot be separated from the existence of advocates in similar legal aid agencies to always provide healing and coaching to the students under the guidance of the lecturers in improving their academic and practical interests in the field of legal proficiency. Thus, it can also be emphasized at the end of this paper, although the student paralegals are faced with various opportunities and challenges, their existence in university legal clinic is now proven to have contributed positively in helping the justice seeker community, and they are also constantly striving to be more progressive in improving legal skills, both in academic, education and training, and also community service in the field of legal aid. This is in line with the adage in Latin: "Ad Limites Legis, Paving via Pro Justitia" which means "Breaking the Boundary of the Law, Paving the Way for Justice".

\section{Bibliography}

Adhha, Nurul, 'Analysis of Causes of Divorce in the Perspective of Islamic Law: A Case Study in the Class 1 A Religious Court of Padang', AL-'ADALAH, 16.1 (2019), 89-114 <https://doi.org/10.24042/ adalah.v16i1.2305>

'Agar Mahasiswa FH Boleh Beracara Di Pengadilan - Hukumonline.Com' <https://www.hukumonline.com/berita/baca/lt51e905308efd3/agarmahasiswa-fh-boleh-beracara-di-pengadilan/>

BKLHK, BKLHK Annual Report 2013-2015, Bandung: Department of Islamic Family Law Faculty of Sharia and Law UIN Sunan Gunung Djati Bandun, 2015.

Carmona, Magdalena Sepúlveda, and Kate Donald, 'Beyond Legal Empowerment: Improving Access to Justice from the Human Rights Perspective', The International Journal of Human Rights, 19.3 (2015), 242-59 <https://doi.org/10.1080/13642987.2015.1029340> 
Cornwall, Andrea, and Celestine Nyamu囚Musembi, 'Putting the "Rights $\mathbb{X}$ based Approach" to Development into Perspective', Third World Quarterly, 25.8 (2004), 1415-37 <https://doi.org/10.1080/01436 59042000308447>

Dancer, Helen, 'Power and Rights in the Community: Paralegals as Leaders in Women's Legal Empowerment in Tanzania', Feminist Legal Studies, 26.1 (2018), 47-64 <https://doi.org/10.1007/s10691-018-9371-6>

- University Legal Clinics: A Comparative Study in BKLHK FSH UIN Sunan Gunung Djati Bandung and FLAP Faculty of Law Monash University Melbourne Australia, Bandung: Puslitpen LP2M UIN Sunan Gunung Djati Bandung, 2016.

'Dirjen Badilag Dan 4 Pimpinan Peradilan Agama Diundang AIPJ Kunjungi Australia | (8/7) - Direktorat Jenderal Badan Peradilan Agama' <https:// badilag.mahkamahagung.go.id/seputar-ditjen-badilag/seputar-ditjenbadilag/dirjen-badilag-dan-4-pimpinan-peradilan-agama-diundang-aipjkunjungi-australia-87>

Editor, 'Paralegal - LBH APIK' <https://lbhapik.or.id/paralegal/>

, 'Peran Dan Fungsi Pekerja Sosial Sebagai Seorang Pendamping Terhadap Anak Yang Berkonflik Dengan Hukum' <http://pnkaranganyar.go.id/main/index.php/berita/artikel/995-peran-danfungsi-pekerja-sosial-sebagai-seorang-pendamping-terhadap-anakyang-berkonflik-dengan-hukum>

, 'Utrecht University School of Law: Clinical Programme on Conflict, Human Rights, and International Justice', International Journal on Human Rights at Utrecht University, 2010

Fathonih, Ah, 'University Legal Clinics In The Fulfillment Of Women And Children Rights', International Journal of Scientific \& Technology Research, 8.4 (2019), 133-40

Holness, Dave, 'Improving Access to Justice Through Compulsory Student Work at University Law Clinics', Potchefstroom Electronic Law Journal, 16.4 (2013), 327-49 <https://doi.org/10.17159/1727-3781/2013/ v16i4a2417>

ILRC, Pendidikan Hukum Klinik: Sebuah Tinjauan Umum, Jakarta: Indonesian Legal Resource Center, 2009. 
Joseph E. Rupp, 'Veterans Legal Clinic - An Integrated Approach to Pro Bono Legal Consultation', Utah BAR Journal, $32.6<<\mathrm{http} / / /$ barjournal. utahbar.org/uploads/9/1/9/4/91940160/nov_dec_2019_final.pdf >.>

Malcolm Bennett, “"Monash Law Clinics"' <Malcolm Bennett,>

Manji, Ambreena, “"Her Name Is Kamundage”: Rethinking Women and Property Among the Haya of Tanzania', Africa, 70.3 (2000), 482-500 <https://doi.org/10.3366/afr.2000.70.3.482>

Marjono, Hartono, Peluang dan Tantangan Pengacara Syariah di Peradilan Agama, Jurnal Mimbar Hukum Number 17 Year, Jakarta: Al-Hikmah and Ditbinpera, 1994.

Maru, Vivek, 'Between Law and Society: Paralegals and the Provision of Justice Services in Sierra Leone and Worldwide', Yale Journal of International Law, 31.2 (2006) <https://digitalcommons.law.yale. edu/yjil/vol31/iss $2 / 5>$

Muliawan, Chandra, 'LBH BANDAR LAMPUNG | Bantuan Hukum di Lampung | Membumikan Bantuan Hukum Struktural Melalui Penguatan Paralegal', LBH Bandar Lampung | Bantuan Hukum Gratis di Lampung $<$ http://bantuanhukumlampung.or.id/opini_lbhbandarlampung.php?judul_ opini =MEMBUMIKAN+BANTUAN+HUKUM+STRUKTURAL+ MELALUI+PENGUATAN+PARALEGAL>

Nurkholis Hidayat, "University Legal Clinics and Its Role in Law Enforcement Program”, presented at the Public Lecturer Discussion, Faculty of Sharia and Law UIN Sunan Gunung Djati Bandung, 2015.

Ramdani Wahyu Sururie, 'The Importance of University Legal Clinics in Public Legal Aid Service' presented at the Public Lecturer Discussion, Bandung: PKHSK Faculty of Sharia and Law UIN Sunan Gunung Djati, 2015.

Ratnaningsih, Erna, 'Peran Paralegal dalam Pemberian Bantuan Hukum', Business Law, 2019 <https://business-law.binus.ac.id/2016/10/16/ peran-paralegal-dalam-pemberian-bantuan-hukum/>

Riyan Ramdani, et.all., Company Profile BKLHK Fakultas Syariah Dan Hukum UIN Sunan Gunung Djati Bandung, Bandung: BKLHK FSH UIN Sunan Gunung Djati Bandung, 2015. 
Siti Aminah dan Muhamad Daerobi, Paralegal Adalah Pemberi Bantuan Hukum, Jakarta: The Indonesian Legal Resource Center, 2019.

Sumner, Cate, 'Memperkuat Layanan Hukum di Perguruan Tinggi', 2019 $<$ ", http://archive.aipj.or.id/en/legal_identity_new/detail/memperkuatlayanan-hukum-di-perguruan-tinggi>

Sumner, Cate, Batagol, Associate Professor Becky, 'University and Community Paralegal Clinics: A Decade of Collaboration between Indonesia and Australia', Themis Says, $2018<$ https:// feministlegalstudies.wordpress.com/2018/12/17/university-andcommunity-paralegal-clinics-a-decade-of-collaboration-betweenindonesia-and-australia/>

Verma, Raj Kumar, 'Role of Para-Legal Services in Administration of Justice: An Empirical Study of Shivpuri District', International Journal of Law, 3.4 (2017), 71-77

Wicaksana, Dio Ashar, 'Pengembangan Klinik Hukum FHUI dan Pembentukan Klinik Anti Korupsi', MaPPI FHUI, 2015 <http:// mappifhui.org/2015/05/01/pengembangan-klinik-hukum-fhui-danpembentukan-klinik-anti-korupsi/>

YLBHI, Verboden Voor Honden En Inlanders dan Lahirnya LBH : Catatan 40 Tahun Pasang Surut Keadian, Jakarta: Yayasan Lembaga Bantuan Hukum Indonesia.

Yogie Arif Maulana, BKLHK Annual Report 2015-2018, Bandung: Department of Islamic Family Law Faculty of Sharia and Law UIN Sunan Gunung Djati, 2018.

Yusup, Deni Kamaludin, Ah. Fathonih, and Burhanuddin, Penguatan Klinik Bantuan Hukum Universitas di PTKIN, Bandung: Puslitpen LP2M UIN Sunan Gunung Djati Bandung, 2019. 